\title{
THE INFLUENCE OF WORK ENVIRONMENT AND WORK STRESS ON EMPLOYEE SATISFACTION AT PT DENKO WAHANA INDUSTRIES
}

\author{
Oki Rinaldi ${ }^{1}$ \\ ${ }^{1}$ Faculty of Economics, Universitas Negeri Jakarta \\ Jakarta, Indonesia \\ okisasau22@gmail.com \\ Dewi Susita ${ }^{2}$ \\ ${ }^{2}$ Faculty of Economics, Universitas Negeri Jakarta \\ Jakarta, Indonesia \\ dewisusita@yahoo.com \\ Agung Wahyu Handaru ${ }^{3}$ \\ ${ }^{3}$ Faculty of Economics, Universitas Negeri Jakarta \\ Jakarta, Indonesia \\ Agung_1178@yahoo.com
}

\begin{abstract}
The purpose of this study was to determine a description of the work environment, job stress and job satisfaction of PT Denko Wahana Industri employees, to test and analyze the effect of work environment on job satisfaction of employees of PT Denko Wahana Industri, to test and analyze the effect of job stress on employee job satisfaction. PT Denko Wahana Industri. This study uses the Partial Least Square (PLS) method to analyze data. The research model used in this research is descriptive explanatory. This study was conducted on 154 employees with a purposive sampling technique. The data collection technique used a survey method, namely distributing questionnaires processed by the SmartPLS 3.3.3 program. PLS results show that there is a significant influence on the work environment and job stress on employee job satisfaction.
\end{abstract}

Keywords: work environment, job stress, job satisfaction. 


\section{INTRODUCTION}

Employees as actors who play the most role in achieving company goals have thoughts, feelings and desires that can influence their attitudes and behaviour at work. The same is the case with PT Denko Wahana Industri. Companies must also pay attention to the welfare of each employee.

Researchers have researched through pre-research questionnaires and interviews. This research is shown for employees of PT Denko Wahana Industri. The benefit of doing this research is to find out the problems that occur. After conducting several interviews, it was found that there was a problem with employee job dissatisfaction. The low job satisfaction that occurs at PT Denko Wahana Industri is indicated by the employee Alpha level, which is increasing every month as shown in the following table:

Table 1. Alpha Data of PT Denko Wahana Industries Employees

\begin{tabular}{|c|c|c|c|}
\hline Month & Total Employees & $\begin{array}{c}\text { Total Employee } \\
\text { Absenteeism }\end{array}$ & Percentages \\
\hline June & 250 & 7 & $3 \%$ \\
\hline July & 250 & 9 & $3,6 \%$ \\
\hline August & 250 & 8 & $3,2 \%$ \\
\hline September & 250 & 8 & $3,2 \%$ \\
\hline October & 250 & 9 & $3,6 \%$ \\
\hline November & 250 & 7 & $4 \%$ \\
\hline December & 250 & 10 & $3 \%$ \\
\hline
\end{tabular}

Table 1 above shows that there is a fluctuation in the level of employee absenteeism every month. The highest level of absenteeism from PT Denko Wahana Industries employees occurred in December with a percentage of $4 \%$. Based on the explanation of the HR manager, the high level of absenteeism of PT Denko Wahana Industries employees was caused by employees often not coming to work without clear information. In addition, the increase in absenteeism of PT Denko Wahana Industri employees was also due to the fact that in December, there are Christmas and New Year 2021 holidays, where people usually take extended leave outside of the red dates and leave together set by the government. This leave-taking is usually done because it is to extend the leave they take. 
Employee attendance can be said to be good if it is at a percentage of 0 to 2 per cent, and the rest is said to be high (Flippo, 2001).

To support the information that has been conveyed orally through interviews, researchers also distributed questionnaires to 40 employees as respondents. The following is a recapitulation of the questionnaire results:

Table 2. Data from PT Denko Wahana Industri's Pre-Research Questionnaire

\begin{tabular}{|c|c|c|c|}
\hline \multirow{2}{*}{ No } & Information & \multicolumn{2}{|c|}{ Percentages } \\
\cline { 3 - 4 } & & Agree & Disagree \\
\hline 1 & Work environment & $87 \%$ & $13 \%$ \\
\hline 2 & Job Stress & $83 \%$ & $17 \%$ \\
\hline 3 & Promotion & $73 \%$ & $27 \%$ \\
\hline 4 & Leadership & $70 \%$ & $30 \%$ \\
\hline 5 & Compensation & $67 \%$ & $33 \%$ \\
\hline 6 & Work motivation & $63 \%$ & $37 \%$ \\
\hline 7 & Work Discipline & $53 \%$ & $47 \%$ \\
\hline 8 & Organizational culture & $50 \%$ & $50 \%$ \\
\hline 9 & Training & $47 \%$ & $53 \%$ \\
\hline 10 & Communication & $33 \%$ & $67 \%$ \\
\hline
\end{tabular}

Based on the data above, from the number of respondents as many as 40 employees of PT Denko Wahana Industri, the most significant percentage is shown in the work environment variable by $86 \%$ and the work stress variable by $83 \%$. The smallest percentage is shown in training by $47 \%$ and communication by $33 \%$. Respondents argued that the low level of work environment is due to an inadequate physical work environment and a non-physical work environment that is less conducive. In addition, a workload that is too high creates high work stress for employees, thus making employees feel a monotonous work cycle without any job satisfaction that the employees themselves deserve.

Job satisfaction is an individual thing, and each individual has a different level of satisfaction according to his wishes and the value system he adopts (Handoko, 2000). This is supported by 
previous research, which states that work environment and work stress have a significant effect on job satisfaction (Kanti Herdian Kusuma, 2020).

The second variable that is thought to affect the job satisfaction of PT Denko Wahana Industri employees is job stress. Job stress is a condition where there is an imbalance between physical and psychological which will affect a person's emotions, thinking patterns, and the condition of an employee and part of this stress can be positive and can be negative (Gofur, 2018). Two factors cause work stress, the first factor is extra-organizational stressors which include things such as social or technological changes, globalization, family, economic and financial conditions, race, class, and living conditions or the surrounding community, and the second factor is organizational stressors which include responsibility without authority, a person's inability to voice complaints, inadequate rewards, lack of clear job descriptions and decreased employee relations (Luthans, 2006).

From interviews with HR managers, researchers got information that employees often complain of easy headaches, fatigue, lack of enthusiasm, often do not focus on doing work, unstable emotional changes. These symptoms are in line with research that explains that work stress has various impacts on symptoms experienced by individuals, including physiological symptoms, psychological symptoms, and behavioural symptoms (Azizah \& Fauzany, 2019). Then supported by research shows that the factors that influence job satisfaction, one of which is job stress (Dhania, 2010). Stress has a positive impact, such as motivation, that can make workers more active in their jobs. If you ignore stress, useless things will arise in the future, so that this will be a negative impact that can affect work, such as decreased work productivity (Arif A, 2010).

Based on this, it is suspected that there is work stress experienced by PT Denko Wahana Industri employees, one of which is caused by work. The work stress that PT Denko Wahana Industri's employees allegedly experienced was due to excessive workloads, which caused From the results of the interview, the researcher also got information that employees felt high enough stress because the work was given more and more. Sometimes employees completed work left by their coworkers without clear directions which made the work pile up and needed more time to complete so that the work collection exceeded the term. The time it should be.

In addition, with the current covid-19 outbreak, the level of stress felt by employees is relatively high because employees are required to work. On the one hand, employees are worried and anxious about being exposed to Covid-19 because production still has to run. Still, the news about the increasing cases of Covid-19 19 makes employees worry about their health while working at the office. 
Based on the background described above, the formulation of the main problems in this study is: What is the description of the work environment, work stress, and job satisfaction of PT Denko Wahana Industri's employees, Does the influence of the work environment affect the job satisfaction of employees of PT Denko Wahana Industri, Does job stress affect employee job satisfaction at PT Denko Wahana Industri.

The research objectives conducted at PT Denko Wahana Industri are as follows: To find a description of the work environment, job stress and job satisfaction of employees at PT Denko Wahana Industri. To determine the effect of the work environment on employee job satisfaction at PT Denko Wahana Industri. To determine the effect of job stress on employee job satisfaction at PT Denko Wahana Industri.

Based on the background on the phenomena found from the results of interviews, pre-research questionnaires obtained from the companies described above, this research is proposed with the title "The Effect of Work Environment and Job Stress on Job Satisfaction of Employees of PT Denko Wahana Industri".

\section{LITERATURE REVIEW}

\section{Job satisfaction}

Job satisfaction is an individual thing because each individual will have a different level of satisfaction according to the values that apply to him. The more aspects of work that suit individual desires, the higher the satisfaction level (Khikmawati, 2015).

Satisfaction is a pleasant feeling resulting from individual perceptions to complete tasks or fulfil their needs to obtain work values that are important to themselves (Wijono, 2010). Job satisfaction is a general attitude towards one's job as the difference between the amount of reward received by workers and the amount of reward that is believed to be received. Job satisfaction is an essential thing that individuals have at work. Each worker has different characteristics, so the level of job satisfaction is also different; job satisfaction can also have different impacts (Robbins, 2015).

Meanwhile, job satisfaction is a happy emotional state or positive emotion from appraising one's job or work experience (Luthans, 2006). From these theories, the authors synthesize job satisfaction as an emotional response from workers - this response, such as satisfying or pleasing the individual to the work he is doing. 


\section{Work environment}

The work environment is defined as a condition related to the characteristics of the workplace towards the behaviour and attitudes of employees where it is related to the occurrence of psychological changes due to things that are experienced in their work or in certain circumstances that must continue to be considered by the organization which includes boredom: work, monotonous work and fatigue (Schultz \& Schultz, 2006).

A work environment is an environment where employees do their daily work (Mardiana, 2005). While the work environment can be interpreted as the complete tooling tool faced, the surrounding environment in which a person works, his work method, influences his work both as an individual and as a group (Simanjuntak, 2003).

The physical work environment is all physical conditions around the workplace that can affect employees either directly or indirectly. Meanwhile, a non-physical work environment is all situations that occur concerning work relationships, both work relationships with superiors and colleagues or relationships with subordinates (Sedarmayanti, 2009).

The work environment is anything or elements that can affect directly or indirectly the organization or company, which will have a good or bad impact on employee performance and job satisfaction (Raziq, 2015).

So from some of the definitions of the work environment above, the researcher synthesizes that the work environment is a condition in the workplace that includes physical and non-physical environments that can provide a sense of security, comfort for employees, and affect performance and levels of job satisfaction more positively.

\section{Job Stress}

Stress is not just nervous tension; stress can have positive consequences, stress is not something to be avoided, and the absence of stress is death. Job stress is defined as an adaptive response to external situations that produce physical, psychological, or behavioural deviations in organizational members (Luthans, 2008).

Job stress is also defined as a dynamic condition in which a person is confronted with opportunities, obstacles, or demands related to what he wants and for which his success is uncertain. So, job stress is defined as a dynamic condition in which individuals face 
opportunities, obstacles, or demands directly faced with what the individual wants. Still, their success is uncertain but essential (Robbins in Sugama, 2017).

Job stress is a pressure due to work that will also affect one's emotions, thought processes and physical conditions, where the pressure comes from the work environment where the individual is (Gyamfi, 2014).

Stress is a feeling of pressure experienced by employees when facing their work. The stress in question can lead to unstable employee emotions, feelings of uneasiness and anxiety, and increased blood pressure to experiencing digestive disorders (Mangkunegara in Noor et al., 2014).

From the definitions that experts have put forward, researchers synthesize that job stress is a condition or feeling of pressure on an employee that can affect their emotions, thoughts and physical conditions in dealing with the same type of stress or condition for each individual and can also be differences pattern of reaction in the workplace.

Based on previous research and the above framework of thinking, it can be stated that there is an influence of work environment and work stress on employee job satisfaction; this framework can be seen in figure 1 as a model of this research:

\section{RESEARCH METHOD}

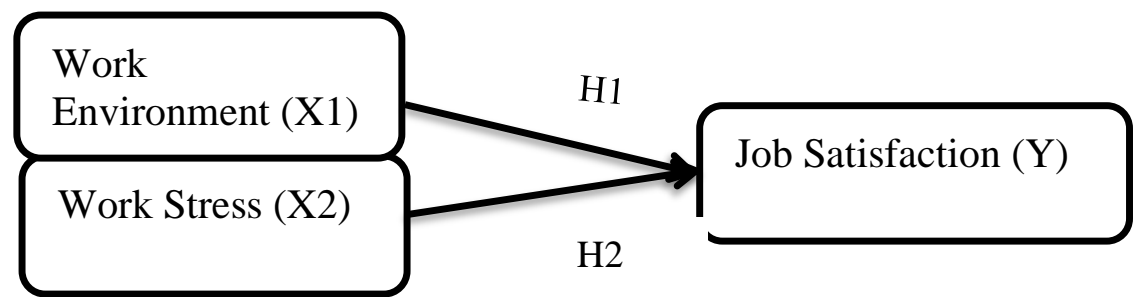

Source: Data processed by researchers (2021)

Figure 1. Research Framework

Information :

$\mathrm{X} 1 \quad$ : Independent variable

X2 : Independent variable

Y : The dependent variable

$\longrightarrow \quad$ : The direction of the variable relationship 
The hypothesis is a provisional assumption, based on the theory and research framework above; the hypothesis in this study are :

Hypothesis $1(\mathrm{H} 1)$

H0 : Work environment has no effect on job satisfaction at employees of PT Denko Wahana Industri

Ha : Work environment affects the job satisfaction of employees PT Denko Wahana Industri

Hypothesis $2(\mathrm{H} 2)$

H0 : Job stress has no effect on job satisfaction at employees of PT Denko Wahana Industri

Ha : Job stress affects the job satisfaction of employees PT Denko Wahana Industri This study analyzes three variables, namely work environment, job stress and job satisfaction. This research is a descriptive and explanatory study from June 2020 to December 2020 with the data collection method using a survey method, namely by using a questionnaire.

The sampling technique used in this study was simple random sampling and purposive sampling conducted by researchers from the total population in this study, as many as 250 people, so that the percentage of leeway used was $5 \%$. Then the sample, which was the respondent in this study, was adjusted to be 154 respondents or $61 \%$ of the total population of PT Denko Wahana Industri.

\section{RESULT AND DISCUSSION}

In PLS, before testing hypotheses, such as analysis in general, Instrument Testing is conducted by evaluating the measurement model (outer model). Testing the router model in PLS consists of three tests, namely convergent validity testing, discriminant validity, and composite reliability / Cronbach's alpha. The value of convergent validity is the value of the loading factor on the latent variable with its indicators (Ghozali and Latan, 2015: 74). In the PLS model, meeting the convergent validity value can be valid if the loading factor value is $>0.5$. Convergent validity describes the ability of each indicator to explain the research variables under study. To determine whether the latent variable indicator is 
valid or not, it is measured by looking at the loading factor value. The latent variable indicator must be greater than 0.5 . The following is a table or matrix in this study.

Table 3. Outer Loading Calculation Matrix

\begin{tabular}{|c|c|c|c|}
\hline Item & $\begin{array}{c}\text { Outer Loading } \\
\text { Minimum }\end{array}$ & $\begin{array}{c}\text { Outer Loading } \\
\text { Results }\end{array}$ & Information \\
\hline \multicolumn{4}{|c|}{ Job Satisfaction (Y) } \\
\hline 1 & 0,5 & 0,798 & Valid \\
\hline 2 & 0,5 & 0,852 & Valid \\
\hline 3 & 0,5 & 0,878 & Valid \\
\hline 4 & 0,5 & 0,870 & Valid \\
\hline 5 & 0,5 & 0,880 & Valid \\
\hline 6 & 0,5 & 0,820 & Valid \\
\hline 7 & 0,5 & 0,892 & Valid \\
\hline 8 & 0,5 & 0,892 & Valid \\
\hline 9 & 0,5 & 0,896 & Valid \\
\hline 10 & 0,5 & 0,856 & Valid \\
\hline 11 & 0,5 & 0,883 & Valid \\
\hline 12 & 0,5 & 0,852 & Valid \\
\hline 13 & 0,5 & 0,885 & Valid \\
\hline 14 & 0,5 & 0,858 & Valid \\
\hline \multicolumn{4}{|c|}{ Work Environment (X1) } \\
\hline 1 & 0,5 & 0,933 & Valid \\
\hline 2 & 0,5 & 0,858 & Valid \\
\hline 3 & 0,5 & 0,934 & Valid \\
\hline
\end{tabular}




\begin{tabular}{|c|c|c|c|}
\hline Item & $\begin{array}{c}\text { Outer Loading } \\
\text { Minimum }\end{array}$ & $\begin{array}{c}\text { Outer Loading } \\
\text { Results }\end{array}$ & Information \\
\hline \multicolumn{4}{|c|}{ Work Environment (X1) } \\
\hline 4 & 0,5 & 0,948 & Valid \\
\hline 5 & 0,5 & 0,909 & Valid \\
\hline 6 & 0,5 & 0,912 & Valid \\
\hline 7 & 0,5 & 0,916 & Valid \\
\hline 8 & 0,5 & 0,870 & Valid \\
\hline \multicolumn{4}{|c|}{ Work Stress (X2) } \\
\hline 1 & 0,5 & 0,917 & Valid \\
\hline 2 & 0,5 & 0,890 & Valid \\
\hline 3 & 0,5 & 0,902 & Valid \\
\hline 4 & 0,5 & 0,931 & Valid \\
\hline 5 & 0,5 & 0,909 & Valid \\
\hline 6 & 0,5 & 0,871 & Valid \\
\hline 7 & 0,5 & 0,906 & Valid \\
\hline 8 & 0,5 & 0,907 & Valid \\
\hline 9 & 0,5 & 0,926 & Valid \\
\hline 10 & 0,5 & 0,942 & Valid \\
\hline 11 & 0,5 & 0,940 & Valid \\
\hline 12 & 0,5 & 0,856 & Valid \\
\hline 13 & 0,5 & 0,900 & Valid \\
\hline
\end{tabular}

The table above shows that all indicators are declared valid because they have a loading factor value above 0.5 . The most significant loading factor value for the job satisfaction variable lies in indicator number 9 , with a value of 0.896 . At the same time, the lowest is 
located in indicator number 1, with a value of 0.798. In the Work Environment variable, the highest loading factor value lies in indicator number 4 with a value of 0.948 , while the lowest is located in indicator number 2 with a value of 0.858 . In the Job Stress variable, the highest loading factor value lies in indicator number 10 with a value of 0.942 , while the lowest is located in indicator number 12 with a value of 0.856 .

\section{Discriminant validity}

The discriminant validity test needs to be done to see the validity of the indicators in measuring the latent variables. An indicator is declared valid if it has the highest loading factor for the intended construct compared to the loading factor correlation of other latent indicators. The following is a cross-loading matrix for discriminant validity tests.

Table 4. Cross Loading Calculation Matrix

\begin{tabular}{|c|c|c|c|}
\hline & $\begin{array}{c}\text { Job } \\
\text { Satisfaction } \\
(\mathbf{Y})\end{array}$ & $\begin{array}{c}\text { Work Environment } \\
(\mathbf{X 1})\end{array}$ & $\begin{array}{c}\text { Work Stress } \\
\text { (X2) }\end{array}$ \\
\hline KK1 & 0,798 & 0,780 & 0,740 \\
\hline KK2 & 0,852 & 0,740 & 0,743 \\
\hline KK3 & 0,878 & 0,778 & 0,779 \\
\hline KK4 & 0,870 & 0,740 & 0,746 \\
\hline KK5 & 0,880 & 0,721 & 0,735 \\
\hline KK6 & 0,820 & 0,685 & 0,695 \\
\hline KK7 & 0,892 & 0,707 & 0,737 \\
\hline KK8 & 0,892 & 0,743 & 0,747 \\
\hline KK9 & 0,896 & 0,757 & 0,774 \\
\hline KK10 & 0,856 & 0,798 & 0,783 \\
\hline KK11 & 0,883 & 0,769 & 0,784 \\
\hline KK12 & 0,852 & 0,758 & 0,749 \\
\hline KK13 & 0,885 & 0,722 & 0,718 \\
\hline KK14 & 0,858 & 0,760 & 0,791 \\
\hline LK1 & 0,797 & 033 & \\
\hline & & & \\
\hline & & & \\
\hline
\end{tabular}




\begin{tabular}{|c|c|c|c|}
\hline & $\begin{array}{c}\text { Job } \\
\text { Satisfaction } \\
\text { (Y) }\end{array}$ & $\begin{array}{c}\text { Work } \\
\text { Environment } \\
\text { (X1) }\end{array}$ & $\begin{array}{c}\text { Work } \\
\text { Stress } \\
\text { (X2) }\end{array}$ \\
\hline LK2 & 0,794 & 0,858 & 0,830 \\
\hline LK3 & 0,786 & 0,934 & 0,857 \\
\hline LK4 & 0,813 & 0,948 & 0,855 \\
\hline LK5 & 0,750 & 0,909 & 0,836 \\
\hline LK6 & 0,746 & 0,912 & 0,810 \\
\hline LK7 & 0,797 & 0,916 & 0,816 \\
\hline LK8 & 0,806 & 0,870 & 0,874 \\
\hline SK1 & 0,802 & 0,804 & 0,917 \\
\hline SK2 & 0,807 & 0,804 & 0,890 \\
\hline SK3 & 0,761 & 0,818 & 0,902 \\
\hline SK4 & 0,802 & 0,809 & 0,931 \\
\hline SK5 & 0,793 & 0,814 & 0,909 \\
\hline SK6 & 0,806 & 0,825 & 0,871 \\
\hline SK7 & 0,786 & 0,863 & 0,906 \\
\hline SK8 & 0,772 & 0,850 & 0,907 \\
\hline SK9 & 0,783 & 0,846 & 0,926 \\
\hline SK10 & 0,810 & 0,878 & 0,942 \\
\hline SK11 & 0,816 & 0,879 & 0,940 \\
\hline SK12 & 0,728 & 0,777 & 0,856 \\
\hline SK13 & 0,785 & 0,907 & 0,900 \\
\hline
\end{tabular}

From the matrix or table above, it can be seen that there are no indicators that can predict variables other than the variables themselves. This can be seen from each indicator's highest loading factor value in the variable column to be measured. Thus, latent variables predict indicators in their block better than indicators in other blocks. 
Table 5. Average Variance Extracted (AVE) Calculation Matrix

\begin{tabular}{|l|l|l|}
\hline Variable & $\begin{array}{l}\text { Average Variance } \\
\text { Extracted (AVE) }\end{array}$ & Information \\
\hline Job Satisfaction (Y) & 0,749 & Valid \\
\hline Work Environment (X1) & 0,829 & Valid \\
\hline Work Stress (X2) & 0,824 & Valid \\
\hline
\end{tabular}

Based on the table above, it can be seen that the variables in this study are job satisfaction $(\mathrm{AVE}=0.749)$, work environment $(\mathrm{AVE}=0.829)$, and work stress $(\mathrm{AVE}=0.824)$, all of which have an AVE value exceeding 0.5 which means that all variables valid.

Table 6. Composite reliability calculation matrix

\begin{tabular}{|l|l|l|}
\hline Variable & Composite Reliability & Information \\
\hline Job Satisfaction (Y) & 0,977 & Reliable \\
\hline Work Environment (X1) & 0,975 & Reliable \\
\hline Work Stress (X2) & 0,984 & Reliable \\
\hline
\end{tabular}

Based on the table above, it can be seen that the variables in this study, namely job satisfaction, work environment, and work stress, all have a Composite Reliabiltiy value exceeding 0.7 which means that all variables are reliable.

Table 7. Cronbach's Alpha Calculation Matrix

\begin{tabular}{|l|l|l|}
\hline Variable & Cronbach's Alpha & Information \\
\hline Job Satisfaction (Y) & 0,974 & Reliable \\
\hline Work Environment (X1) & 0,970 & Reliable \\
\hline Work Stress (X2) & 0,982 & Reliable \\
\hline
\end{tabular}

Based on the table above, it can be seen that the variables in this study, namely job satisfaction, work environment, and work stress all have a Cronbach's Alpha value exceeding 0.7 which means that all variables are reliable.

\section{Descriptive Analysis Results}

The results of descriptive analysis for each variable used in this study, namely the variables of job satisfaction, compensation and career development, can be seen from the results of the descriptive analysis of each variable. The data description is the result of processing from the raw data of research variables intended to provide an overview of the 
distribution and distribution of the research data obtained through distributed questionnaires.

If you look at the description of the dimensions, it can be concluded that the job satisfaction of the employees of PT Denko Wahana Industri is low. This can be seen from the three indicators of the six dimensions that have a value above $61.01-84 \%$, namely in the statement "The current job assignment is in accordance with the skills I have" with the answer disagree (ts) and strongly disagree ( sts) of $76.63 \%$ and also in the statement "I receive my salary on time" with a total percentage of strongly disagree (sts) and disagree (ts) $77.27 \%$. Then in the statement "I feel the promotion system in the company has been carried out fairly", with a total percentage of strongly disagree (sts) and disagree (ts) $76.63 \%$.

If you look at the description of the dimensions, it can be concluded that the work environment at PT Denko Wahana Industri is terrible. This can be seen from two indicators from two dimensions that have values above $61.01-84 \%$, namely in the statement "The air circulation in my work room is good enough" with the answers disagree (ts) and strongly disagree (sts) of $75.33 \%$ and also on the statement "The relationship between employees and leaders helps me in working" with the total percentage strongly disagree (sts) and disagree (ts) $75.33 \%$.

If you look at the description of the dimensions, it can be concluded that the work stress of the employees of PT Denko Wahana Industri is high. This can be seen from three indicators from six dimensions that have values above 61.01-84\%; namely, the statement "The noise of my workplace interferes with my concentration at work" with the answers disagree (ts) and strongly disagree (sts) of 74, 68\% and also the statement "Too long staring at the monitor screen makes my eyes tired quickly" with the total percentage strongly disagree (sts) and disagree (ts) 74.68\%. Then in the statement "The room where the work is always cleaned", the total percentage strongly disagree (sts) and disagree (ts) $74.68 \%$.

\section{Hypothesis test}

The hypothesis test conducted in this study is the test with a significance level of 5\% and the decision criterion $\mathrm{H} 0$ is rejected if the $\mathrm{p}$-value is $\leq 5 \%$. Or tstatistik $>$ ttable (1.96). The following is a table of path coefficients and the $t$ test. 
Table 8. Matrix Calculation of Path Coefficients

\begin{tabular}{|l|l|l|l|l|l|}
\hline & $\begin{array}{l}\text { Original } \\
\text { Sample } \\
(\text { O) }\end{array}$ & $\begin{array}{l}\text { Sample } \\
\text { Mean (M) }\end{array}$ & $\begin{array}{l}\text { Standard } \\
\text { Deviation } \\
(\text { STDEV })\end{array}$ & $\begin{array}{l}\text { T Statistics } \\
(\mid \text { O/STDEV }\end{array}$ & $\begin{array}{l}\boldsymbol{P} \\
\text { Values }\end{array}$ \\
\hline $\begin{array}{l}\text { Work environment } \\
(\mathrm{X} 1)-> \\
\text { Job Satisfaction (Y) }\end{array}$ & 0,420 & 0,417 & 0,101 & 4,164 & 0,000 \\
\hline $\begin{array}{l}\text { Job Stress (X2) -> } \\
\text { Job Satisfaction (Y) }\end{array}$ & 0,482 & 0,486 & 0,104 & 4,635 & 0,000 \\
\hline
\end{tabular}

Hypothesis 1:

Ho : The work environment has no effect on the job satisfaction of employees of PT Denko Wahana Industri

Ha : Work environment affects the job satisfaction of employees of PT Denko Wahana Industri

Based on the bootstrap estimation using a sample of 154 in the table above, the $\mathrm{T}$ statistical value for the first hypothesis is that the effect of work environment on job satisfaction is 4.164 (greater than 1.96), and a p-value $\leq$ of 0.05 is 0.000 (smaller than $\alpha$ $=0.05)$ then $\mathrm{H} 0$ hypothesis 1 is rejected, and $\mathrm{Ha}$ is accepted, which means that there is a positive and significant influence between the work environment on the job satisfaction of employees of PT Denko Wahana Industri. These results are consistent with Agustina Kombong (2015), Aulya Rahman, Surya Dharma, Reni Yuliviona (2016), and Adveni Aoliso \& Hans Lao (2018), who also examined Work Environment influence on Job Satisfaction.

Hypothesis 2:

Ho : Job stress has no effect on job satisfaction of employees of PT Denko Wahana Industri

Ha : Job stress affects the job satisfaction of employees of PT Denko Wahana Industri 
Based on the bootstrap estimation using a sample of 154 in the table above, the $\mathrm{T}$ statistical value for the second hypothesis is that the effect of job stress on job satisfaction is 4.635 (greater than 1.96), and a p-value $\leq$ of 0.05 is 0.000 (smaller than $\alpha=0.05$ ) then $\mathrm{HO}$ hypothesis 2 is rejected, and Ha is accepted, which means that there is a positive and significant influence between job stress on job satisfaction of employees of PT Denko Wahana Industri. These results follow the research conducted by Kiki Retno Sari (2018), Adeel Akhtar, Khawar Naheed, Shakil Akhtar and Usman Farooq (2018), and Butt et al. (2020), who also examined the effect of Job Stress on Job Satisfaction.

\section{CONCLUSION}

Industry. After testing and analyzing research data on "the influence of work environment and job stress on job satisfaction of employees of PT Denko Wahana Industri", the following conclusions are obtained: This study shows that PT Denko Wahana Industri has low job satisfaction. This is indicated by the low level of work itself owned by PT Denko Wahana Industri. This is due to the current job assignments that are not following the abilities and skills possessed by the employees of PT Denko Wahana Industri. In addition, what shows the low job satisfaction at PT Denko Wahana Industri is the low salary owned by PT Denko Wahana Industri's employees; this is because the company does not provide salaries on time and assign tasks that are not following the job responsibilities of PT Denko Wahana employees.

This research shows that PT Denko Wahana Industri has a lousy work environment. This is shown by the poor physical work environment that PT Denko Wahana Industri owns, and this is because the air circulation in the employee workspace is not good enough. There is no guarantee of security that is owned by the employees of PT Denko Wahana Industri. In addition, the poor working environment at PT Denko Wahana Industri is the non-physical work environment at PT Denko Wahana Industri; this is because of PT Denko Wahana Industri employees.

This research shows that PT Denko Wahana Industri has high work stress. This is indicated by the high physical demands possessed by PT Denko Wahana Industri. This is because workplace noise interferes with employee concentration at work, and staring at the monitor screen makes the eyes of PT Denko Wahana Industri's employees. The 
industry is a demanding job for PT Denko Wahana Industri employees; this is because employees feel that daily working hours are burdensome, work and tasks tend to be boring for PT Denko Wahana Industri employees.

Based on the conclusions that have been stated above, the researcher can express some suggestions, namely as follows: first, the company should consider adding or improving existing facilities in the company to make it easier or help employees in their work. Second, the company should consider giving more detailed directions on every job that the employee will do. Third, the company should form a work team that can form solidarity between employees and build teamwork.

\section{References}

Abdillah, Jogiyanto, (2015), Partial Least Square Alternatif SEM dalam penelitian bisnis. Yogyakarta : penerbit ANDI.

Afrizal, P. R, Musadieq, M. A. \& Ruhana, I. (2014).Pengaruh Konflik Kerja dan Stres Kerja terhadap Kepuasan Kerja (Studi pada Karyawan PT TASPEN (PERSERO) Cabang Malang. Jurnal Administrasi Bisnis. 8(1), 1-10.

Arikunto, Suharsimi (2009). Prosedur Penelitian Suatu Pendekatan Praktik. Jakarta: Rineka Cipta.

As'ad, Moh. (2014). Psikologi Industri. Yogyakarta : Liberty.

Aziz, Andi Abdul dan Dedi Purwana, I Ketut R. Sudiarditha (2020). Soldier Performance: The Role of Leadership Style, Work Environment, and Work Discipline (Finding From Navy Command Fleet, Indonesia. Jurnal Dinamika Manajemen Dan Bisnis, 3(2), 37-57. http://journal.unj.ac.id/unj/index.php/jdmb/article/view/20677/10584

Cooper, Cary, Straw, Alison (2005). Stres Manajemen Sukses Dalam Sepekan. Jakarta: Kesaint Blanc.

Daft, L Richard (2006). Manajemen. Edisi Keenam. Jakarta: Salemba Empat. 
Ghozali, Imam. (2011). Aplikasi Analisis Multivariate Dengan Program IBM SPSS19. Semarang: Universitas Diponegoro.

Ghozali dan Latan. (2015). Partial Least Square konsep teknik dan aplikasi menggunakan program smart PLS 3.0 edisi 2. Semarang: Badan Penerbit Universitas Diponegoro.

Gibson, JL. Ivancevich, JM. Anda Donelly Jr. JH. (1998). Organisasi Perilaku,Struktur, Proses. Erlangga.

Handoko, T, Hani (2011). Manajemen Personalia dan Sumber Daya Manusia. Yogyakarta: BPFE Jogjakarta.

Hasan, M Iqbal (2012). Pokok-pokok materi metodologi penelitian dan aplikasinya. Bogor: Ghalia Indonesia.

Hasibuan, Malayu (2004). Manajemen Edisi Revisi. Jakarta: Bumi Aksara.

Hasibuan, Malayu (2013). Manajemen Sumber Daya Manusia. Jakarta: Bumi Aksara.

Kadarisman, Dr. M. Manajemen Kompensasi (2012). Jakarta: Raja Grafindo Persada.

Kurniawan, Iwan dan Dewi Susita. (2020). The Effect Of Leadership Style And Motivation On The Quality Of Work Life With Organizational Commitment As Intervening Variables. Jurnal Dinamika Manajemen Dan Bisnis, 3(2), 127. http://journal.unj.ac.id/unj/index.php/jdmb/article/view/20907/10582

Luthans, Fred (2006). Perilaku Organisasi. Edisi Sepuluh. Yogyakarta: Andi.

Lukiyanto, Irwan. "Pengaruh Kompensasi Finansial dan Stres Kerja Terhadap Kepuasan Kerja Karyawan”. Universitas Negeri Surabaya. 2014. Jurnal Vol 2, No. 1 .

Mangkunegara, Anwar Prabu (2005). Sumber Daya Manusia perusahaan. Bandung: Remaja Rosdakarya. 
Tunjungsari, Peni (2011). "Pengaruh Stres Kerja Terhadap Kepuasan Kerja Karyawan Pada Kantor Pusat PT. Pos Indonesia (Persero) Bandung”. Fakultas Ekonomi Universitas Komputer Indonesia. 2011. Jurnal Vol 1, No. 1.

Ubaidilah, B (2007). Manajemen Sumber Daya Manusia dan Perilaku Organisasi. Jakarta: Erlangga.

Umar, Husein (2008). Desain Penelitian MSDM dan Perilaku Karyawan: Paradigma Positiyistik dan Berbasis Pemecahan Masalah. Edisi I, Cetakan Pertama. Jakarta: Raja Grafindo Persada.

Veithzal, Rivai (2008). Manajemen Sumber Daya Manusia untuk Perusahaan. Jakarta: Raja Grafindo Persada.

Veithzal, Rivai dan Jauvani, Ella Sagala (2009). Manajemen Sumber Daya Manusia Untuk Perusahaan. Jakarta: Rajawali Pers.

Veithzal, Rivai (2014). Manajemen Sumber Daya Manusia untuk Perusahaan, Edisi ke 6, PT. Raja Grafindo Persada, Depok, 16956.

Wahyu Handaru, Agung dan Try Utomo (2013). "Pengaruh Lingkungan Kerja, Kompensasi, dan Komitmen Organisasi terhadap Kepuasan Kerja Karyawan di PT. X”. Jurnal Riset Manajemen Sains Indonesia. Universitas Negeri Jakarta.

Wahyudi, Amin dan Suryono, Jarot (2006). "Analisis Pengaruh Gaya Kepemimpinan, Motivasi, dan Lingkungan Kerja terhadap Kinerja Pegawai”. Jurnal Manajemen Sumber Daya Manusia. Vol 1, No. 1.

Wijono, Sutarto. (2010). Psikologi Industri \& Organisasi. Jakarta: Kencana.

Wursanto (2005). Dasar Dasar Ilmu Organisasi. Yogyakarta: Andi. 